\title{
Song Using Medicare Prices, ACA Marketplace
}

\section{TO THE EDITOR:}

Song (1) proposed a reliable method of using Medicare prices for equity and affordability in Affordable Care Act (ACA) marketplace. The question remains, are coverage policies similar to Medicare? Health insurance is a financial mechanism for paying for healthcare, while access refers to the process of actually obtaining that care $(2,3)$. Without appropriate considerations, recipients may suffer diminution of critical elements of access with high deductibles and copays similar to Medicare Advantage Plans. Further, it may also be helpful to survey practices in wide geographic areas in different specialties and map alongside payments of commercial insurers, which may not be as rosy as overall projected reimbursement profiles.

Commercial payers and Medicare Advantage Plans have utilized numerous techniques of denying care and at the same time included significant copays and deductibles. Song's approach will thus not only reduce costs for ACA Marketplace, but improve patient care through greater access.

\author{
Laxmaiah Manchikanti, MD \\ Clinical Professor \\ Anesthesiology and Perioperative Medicine \\ University of Louisville, Louisville, Kentucky \\ Professor of Anesthesiology-Research \\ Department of Anesthesiology, School of Medicine \\ LSU Health Sciences Center, New Orleans, Louisiana \\ Medical Director \\ Pain Management Center of Paducah \\ 2831 Lone Oak Road \\ Paducah, KY 42003 \\ E-mail: drlm@thepainmd.com \\ Joshua A. Hirsch, MD \\ Vice Chief: Interventional Care \\ Massachusetts General Hospital \\ Associate Professor of Radiology \\ Harvard Medical School \\ Affiliate Senior Research Fellow \\ Neiman Health Care Policy Institute \\ Boston, MA \\ E-mail: HIrsch@snisonline.org
}

\section{References}

1. Song Z. Using Medicare prices - Toward equity and affordability in the ACA marketplace. N Engl J Med 2017;377:2309-11.

2. Obama B. United States health care re- form: Progress to date and next steps. JAMA 2016;316:525-32.

3. Manchikanti L, Helm $S$ 2nd, Benyamin RM, Hirsch JA. A critical analysis of
Obamacare: Affordable care or insurance for many and coverage for few? Pain Physician 2017;20:111-38. 